\title{
Ultrasound in Pregnancy during the Corona-Virus Pandemic: a Practical Approach
}

\author{
Ultraschall in der Schwangerschaft während der Corona-Virus Pandemie: \\ Ein praktisches Vorgehen
}

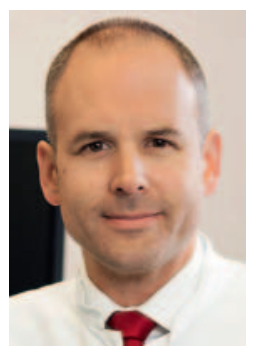

Prof. Karl Oliver Kagan

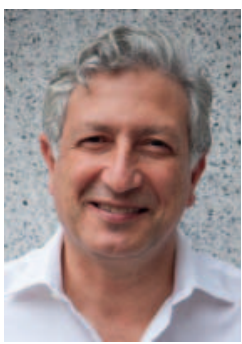

Prof. Rabih Chaoui
Correspondence

Prof. Dr. Karl Oliver Kagan

Dpt. of Obstetrics and Gynecology - University of Tübingen

Calwerstraße 7, D-72076 Tübingen

KOKagan@gmx.de

Prof. Dr. med. Rabih Chaoui

Prenatal Diagnostic Center

Friedrichstrasse 147, D-10117-Berlin

chaoui@feindiagnostik.de

Bibliography

DOI https://doi.org/10.1055/a-1152-4550

Published online: April 8, 2020

Ultraschall in Med 2020; 41: 237-243

(c) Georg Thieme Verlag KG, Stuttgart · New York

ISSN 0172-4614
The corona virus pandemic, which began in December 2019, has presented humanity with a major challenge within a short span of three months. Government and health care agencies around the world are developing measures to reduce the spread of the pandemic, provide adequate care for infected patients and reduce mortality to the lowest level possible. Near complete shutdown of services and social distancing substantially changed the lives of millions of people and paralysed public and professional life in most countries.

In medical practices, the primary focus is currently on the care of COVID-19 infected patients. Furthermore, despite reducing elective surgeries and patient visits, antenatal care remains essential for the safety of mother and child and is therefore still provided in most countries. Healthcare providers involved in the care of pregnant women are still actively providing care and face significant daily challenges in the outpatient and inpatient setting.

Given the unprecedented nature of this crisis and the lack of experience in dealing with such, our ability to provide answers to our pregnant women and solutions to our staff is limited by the lack of scientific data to guide us along this process. Emerging data provide information with regards to the impact of COVID-19 infections in pregnancy and particularly regarding the care and delivery of infected pregnant women and perinatal transmission $[1,2]$.

In this editorial we will first concentrate on the current state of knowledge with regards to Covid-19 in pregnancy and present some considerations on how to design your own workplace and how to perform the ultrasound examination. In view of the large number of questions that have been posed to us over the past several weeks and that will continue to arise in the future, this overview cannot be conclusive, but reflects our understanding at this time.

It is important to note that this editorial reflects the experience of the authors in their respective centers and should be construed to represent national or international guidelines, several of which have already been published and can be found at the corresponding websites [1-9].

\section{Summary of the clinical course of infection in pregnancy}

The novel coronavirus is officially called SARS-CoV-2 because of its similarity to the coronavirus which causes SARS. The WHO gives a R0 value of $2-2.5$, which indicates that one person infects 2-2.5 others. The overall mortality rate is given as about $3.5 \%$. About $80 \%$ of those infected are mildly affected or asymptomatic, $15 \%$ are severely oxygen-deprived and $5 \%$ require artificial respiration [10]. Here, however, reference must be made to the currently unknown number of asymptomatic infections.

Half of symptomatically infected individuals develop symptoms within the first 5 days, and about $90 \%$ within 14 days [11]. The clinical picture is heterogeneous and does not differ between 
pregnant and non-pregnant women. The main symptoms are fever ( $84 \%)$, cough (28\%), dyspnoea (18\%) as well as leucocytosis and lymphopenia (38\% and $22 \%$ ). Typical pneumonia-related changes were found in the CT scans of three quarters of symptomatic patients [12]. This underlines the similarity to SARS and MERS, although the latter diseases are more often fatal.

There is little data available about COVID-19 in pregnant women, newborns and women in childbed, which suggests that the course of the disease is less problematic in this group.

Dashraath et al. summarized 55 published pregnancies of women with Covid 19. Miscarriage occurred in $2 \%$ of cases, growth retardation in $10 \%$ and preterm birth in 39\% [12]. Neonatal development was not summarized in this case series. However, other working groups report a low disease score [13]. So far there is no evidence of a teratogenic effect. There is no reliable evidence for vertical mother-to-child transmission [14, 15].

\section{"Social distancing" and shortened examinations are the order of the day}

As prenatal medicine experts, we are responsible for the care of pregnant women, both in community practice and in the clinic. This includes preventing infection, not neglecting our health to ensure care, and still offering and carrying out all the necessary examinations. Under the assumption that every pregnant woman could potentially be infected, "social distancing" and shortened examinations are the focus of our actions.

This begins with planning appointments. No more than one waiting patient per ultrasound room should be present in the waiting room. This can be achieved by reducing the number of appointments, or at least by extending the number of scheduled patients over a longer period of time. At the same time, the appointment should be accompanied by an appeal to cancel the appointment if it is not required. Failure to attend an appointment is an even greater economic challenge than usual if the number of patients is reduced.

The presence of partners and children should be avoided. This should already be clearly pointed out when making an appointment to avoid time-consuming discussions at the entrance. Accompanying persons waiting in front of the practice or clinic rooms also pose a risk of infection. If necessary, the rules of conduct could be sent to the patients again in advance by e-mail.

When making an appointment, the question arises as to whether the examination is promptly indicated or whether a later assessment - for example as part of the third screening - is also sufficient. Typical examinations that can be postponed involves inadequate visualization of a single organ system. The same applies to increased resistance in the uterine artery at the second trimester scan or close monitoring of a shortened cervix in patients without contractions. In principle, we should be guided by the consequence of the examination at each screening. If the management does not alter, the screening can initially be postponed.
A similar train of thought should also be used during an examination: the advantage of a shorter examination outweighs the disadvantage of a perfection-oriented examination. The aim should be that the pregnant woman stays as briefly as possible in a closed room with the doctor. During the detailed screening examination in the second trimester, the examiner is usually less than one meter away from the pregnant woman. Because of the length of the examination and the proximity to the patient, the doctor is already considered a category lb contact person according to the WHO guidelines if it subsequently turns out that the pregnant woman was infected and if she did not wear a mask $[16,17]$.

Therefore, an attempt should be made to reduce the time spent together with the pregnant woman in one room, and simple measures can help. For example, the written report can be produced when the patient has left the room after the examination. Some structures can also be measured and documented using the stored images without the presence of the pregnant woman. Some centres abroad recommend saving video clips and $3 \mathrm{D}$ volumes and transferring the images afterwards as a possible way of shortening doctor-patient contact.

However, this does not mean that necessary examinations should be avoided. This primarily includes adequate follow-up of suspected malformations in the usual way with the option of invasive testing. An invasive procedure should not be performed in the context of a manifest infection - with COVID-19, however, this is generally determined by the maternal symptoms.

Adequate first trimester screening with a focus on early assessment of the anatomy, as well as pre-eclampsia and aneuploidy screening should not be avoided - especially with regard to planning pregnancy [18]. But here too, the question arises as to the consequence of an abnormal or inconspicuous result. For the benefit of a shortened examination, can pre-eclampsia screening in a first-time mother without risk factors also be waived, or must the early detailed diagnosis include the mouth area?

There are sufficient reasons for detailed screening in the second trimester. To list them would go beyond the scope of this paper. These reasons, of course, also currently remain valid. However, second trimester screening allows greater flexibility in terms of time and can easily be carried out at a later date, possibly even in combination with the third trimester screening. Again, the above-mentioned aspects of rationing doctor-patient contact for infection prevention apply. However, this advantage is offset by the disadvantage of the possible late diagnosis of a complex malformation.

\section{Organizing your own practice}

Optimal planning of the consultation process has already been discussed and is intended to reduce the probability of infection in the workplace. Many procedures can also be optimised during the patients' visits to the practice or clinic.

The approaches shown here are intended as suggestions and do not represent a complete list. 


\section{Triage of pregnant women prior to entering the clinic}

- Patients should come alone.

- On arrival to the clinic, the pregnant woman should be questioned with regards to her symptoms and an assessment of the level of risk should be performed.

- The patient should be given the opportunity to wash and/or disinfect her hands intensively (30 sec).

- The waiting room should be rearranged to provide a distance of $2 \mathrm{~m}$ between patients. It is advisable to have a plexiglass protection between the patient and clinic staff at registration.

- In the event of a suspected case or a contact person, it is advisable to question the indication for the examination. If absolutely necessary to see the patient, she should be scheduled at the end of clinic after all other pregnant women have already left the waiting room and she should interact with the minimal number of staff.

- When possible, suspected cases should be postponed for 14 days

- Symptomatic pregnant women, especially patients with dyspnea, should be sent to the emergency department.

\section{Preparation for the examination}

- If the premises allow, a separate examination room should be provided for suspected cases and contacts, which is not used for other purposes. This room should contain only the necessary examination material.

- For the investigation of suspected cases and contacts, a full protective suit, FFP2/3 mask, double gloves and safety glasses should be worn before the patient enters the room.

- The examination of suspected cases and contact persons should be carried out by an experienced physician to conclude the investigation as quickly and efficiently as possible.

- Both the surfaces of the ultrasound device and the transducers as well as the couch and the computer workstation (especially the keyboard, mouse, telephone) and other frequently touched surfaces (e.g. light switches and pens) in the examination room should be thoroughly cleaned and disinfected following the examination. Mobile phones are also potential sources of pathogens.

- Ultrasound gel from small disposable containers should be used to avoid potential pathogen reservoirs.

- Disposable paper towels are preferable to cotton cloths, and especially towels brought from home. If cloth is still being used, it should be stored separately and washed at over $60^{\circ} \mathrm{C}$.

- If possible, pregnant women should be motivated to also wear a mouth-nose protection mask (self-sewn or surgical mask) when entering the clinic/practice. The aim is mainly to protect other patients and staff from infection when they speak, cough or sneeze.

\section{During the examination}

- Put on gloves and wash or disinfect hands before and after the examination and use skin care products.

- Wear a face mask that is intended to protect you from the spread of COVID-19. A common mouth-nose mask or FFP1 mask does not reduce the risk of infection, only the risk of spread.

According to the Robert Koch Institute (the German Center for Infection Control), wearing an FFP 2/3 mask and gloves during the examination means that quarantine can be waived if the pregnant woman subsequently develops an infection provided, of course, that there are no symptoms.

- Anyone who wears an FFP 2/3 mask for their own protection will not be able to speak very much during the examination. Sufficient preparatory and follow-up discussion with the pregnant woman should therefore be considered, during which there should be a distance of at least $2 \mathrm{~m}$ between the doctor and the patient. During the preliminary discussion, written explanations in advance can be helpful.

- If possible, all examinations, for example blood tests, should be carried out in one room and unnecessary room changes should be avoided.

- The number of people in a room should be kept to a minimum. During this time, every additional person such as students, guest doctors and trainees represents an additional potential source of infection.

Overall, the entire examination process should be kept as short as possible.

\section{After the examination}

- The examination room should be ventilated after every second patient. This allows the staff to take breaks and to take off the strenuous FFP mask for a short time.

- According to the Robert Koch Institute guidelines, FFP masks and mouth-nose protection masks can be used several times by the respective person if there is a shortage of material, but only if they have not been contaminated or soaked [19].

- SARS-V2 is a virus that can be removed with simple soap (surfactants) and disinfection. After the examination, the abdominal transducer should be wiped dry and cleaned accordingly [20]. Ideally, a disinfectant wipe can be used, but if there is a shortage of disinfectants, alternatives must be used.

- Regular checks on your own team should also reveal potential sources of infection. While regular PCR and antibody-based tests are currently not possible, it is still possible to simply measure the temperature and query the typical symptoms.

- Team meetings should be temporarily avoided. Alternatively, they should be web-based.

- Even during breaks, the need for distance between employees should be taken into account.

- Since the global and own situation is perceived by many as an existential threat, sufficient opportunity should be given for mutual exchange. If necessary, fears can be resolved in a moderated conversation. 


\section{Summary}

As we learn more about COVID-19, we are putting processes in place to help provide better care for our pregnant population and protect our staff and healthcare workers. On the one hand, we continue to stand for high quality in prenatal care and care for high-risk pregnancies, on the other hand, we do not want to endanger the pregnant woman, our employees or ourselves. We hope that this editorial provide you with useful information to help in setting up your clinic to protect patients and your workers.

\section{Ultraschall in der Schwangerschaft während der Corona-Virus Pandemie: Ein praktisches Vorgehen}

Die Corona-Pandemie hat mit ihrem Beginn im Dezember 2019 innerhalb von drei Monaten die Menschheit vor eine große Herausforderung gestellt. Weltweit erarbeiten Regierungen und Mediziner Maßnahmen, um die Ausweitung der Pandemie zu reduzieren, erkrankte Menschen adäquat zu versorgen und die Mortalität so niedrig wie möglich zu halten. Der „shut down“ und das „social distancing“ haben das öffentliche und berufliche Leben in den meisten Ländern paralysiert.

In der medizinischen Betreuung konzentrieren sich die Kräfte auf Coronavirus-infizierte PatientInnen und Notfälle. Gleichzeitig bleibt die Schwangerenvorsorge aber für die Sicherheit von Mutter und Kind essentiell und wird daher in den meisten Ländern auch weiterhin durchgeführt. Pränatalmediziner - ob im Kreißsaal oder in der Ambulanz, ob in der Klinik oder in der Niederlassung gehören zu den Leistungserbringern während der Corona-Pandemie. Sie arbeiten weiter und stehen täglich vor neuen Herausforderungen.

Eine vergleichbare Situation haben wir noch nicht erlebt. Daher gibt es auch keine Vorerfahrungen, auf die wir zurückgreifen können. Viele Fragen werden von den Schwangeren und unseren Mitarbeitern in diesem Zusammenhang aufgeworfen, ohne dass eine wissenschaftlich begründete Antwort gegeben werden kann. Diese betreffen sowohl die Maßnahmen des Infektionsschutzes als auch die Schwangerschaft selbst in Zeiten der Virusgefahr. Für manche Aspekte zeichnet sich eine Klärung ab, insbesondere was die Betreuung und Entbindung von infizierten Schwangeren sowie die prä- und peripartale Transmission betrifft $[1,2]$.

In diesem Editorial wollen wir uns zunächst auf Eckdaten zu der Coronavirus-Infektion und Covid-19 in der Schwangerschaft konzentrieren und im Anschluss einige Überlegungen zur Ausgestaltung des eigenen Arbeitsplatzes und zur Durchführung der Ultraschall-Untersuchung aufzeigen. Angesichts der Fülle an Fragen, die sich uns in diesem Kontext in den vergangenen Tagen gestellt haben und sich auch zukünftig ergeben, kann dieser Überblick nicht abschließend sein.

Die Überlegungen spiegeln die aktuellen und empirischen Erfahrungen der Autoren in deren Zentren wider, ohne evidenzbasiert zu sein. Für andere Fragen zu Covid-19 und Schwangerschaft verweisen wir auf die nationalen und internationalen Stellungnahmen [1-9].

\section{Zusammenfassung des klinischen Verlaufs der Infektion in der Schwangerschaft}

Das neuartige Coronavirus wird aufgrund seiner Ähnlichkeit zum SARS auslösenden Coronavirus offiziell SARS-CoV-2 genannt. Die WHO gibt einen R0-Wert von 2-2,5 an, was indiziert, dass eine Person 2-2,5 weitere ansteckt. Die Sterblichkeit wird insgesamt mit etwa 3,5\% angegeben. Etwa $80 \%$ der Infizierten sind mild betroffen oder asymptomatisch, $15 \%$ schwer mit Sauerstoffbedarf und $5 \%$ sind beatmungspflichtig [10]. Hier muss aber auf die bisher nicht bekannte Dunkelziffer an asymptomatischen Infektionen hingewiesen werden.

Die Hälfte der symptomatisch Infizierten entwickelt innerhalb der ersten 5 Tage Symptome, etwa 90 \% innerhalb von 14 Tagen [11]. Das klinische Bild ist heterogen und unterscheidet sich bei erkrankten Schwangeren nicht von dem nicht schwangerer Patientinnen. Führend sind Fieber (84\%), Husten (28\%), Dyspnoe (18\%) sowie Leukozytose und Lymphopenie (38\% und $22 \%$ ). Bei den symptomatischen Patientinnen fand sich in drei Viertel der Fälle Pneumonie-typische Veränderungen im CT [12]. Dies unterstreicht die Ähnlichkeit zur SARS und MERS, wenn auch die letztgenannten Erkrankungen häufiger fatal verlaufen.

Die Datenlage von COVID-19 erkrankten Schwangeren, Entbundenen und Neugeborenen ist dünn, was dafür spricht, dass der Verlauf in diesem Kollektiv seltener problematisch ist.

Dashraath et al. fassten 55 publizierte Schwangerschaften von Frauen mit Covid 19 zusammen. In $2 \%$ der Fälle kam es zu einer Fehlgeburt, in $10 \%$ zu einer Wachstumsretardierung und in $39 \%$ zu einer Frühgeburt [12]. In dieser Fallserie wurde der Verlauf bei den Neugeborenen nicht zusammengefasst. Jedoch berichten andere Arbeitsgruppen von einem geringen Krankheitswert [13]. Hinweise auf einen teratogenen Effekt gibt es bisher nicht. Für eine vertikale Mutter-Kind-Transmission gibt es bisher keine gesicherten Hinweise [14, 15].

\section{„Social Distancing“ und verkürzte Untersuchungen als Gebot der Stunde}

Sowohl in der Niederlassung als auch in der Klinik tragen wir als Pränatalmediziner Verantwortung für die Versorgung der Schwangeren. Dazu gehört, dass wir Infektionswege unterbinden, unsere Gesundheit zur Sicherstellung der Versorgung nicht vernachlässigen und trotz allem alle notwendigen Untersuchungen anbieten und durchführen. Unter der Voraussetzung, dass jede Schwangere potentiell infiziert sein könnte, stehen das „social distancing“ und verkürzte Untersuchungen im Mittelpunkt unseres Handelns.

Dies beginnt bei der Terminplanung. Pro Ultraschall-Raum sollte im Wartezimmer nicht mehr als eine wartende Patientin anwesend sein. Dies lässt sich durch eine Reduktion der Einbestellung oder zumindest durch eine Streckung der einbestellten Patientinnen über einen längeren Zeitraum erreichen. Gleichzeitig sollte die Terminvereinbarung auch mit dem Appell verbunden sein, den Termin tatsächlich abzusagen falls er nicht in Anspruch genommen wird. Nicht erscheinende Patientinnen sind bei redu- 
zierter Einbestellung eine noch größere wirtschaftliche Herausforderung als sonst.

Auf die Anwesenheit der PartnerInnen und der Kinder sollte verzichtet werden. Darauf sollte bereits bei der Terminvereinbarung deutlich hingewiesen werden, um aufwendige Diskussionen am Eingang zu vermeiden. Auch vor den Praxis- oder Klinikräumen wartende Begleitpersonen stellen ein Infektionsrisiko dar.

Gegebenenfalls könnten die Verhaltensregeln nochmals per E-Mail vorab an die Patientinnen versendet werden.

Bei der Terminvereinbarung stellt sich die Frage, ob die Untersuchung tatsächlich zeitnah indiziert ist oder ob eine spätere Kontrolle, zum Beispiel im Rahmen des dritten Screenings nicht auch ausreichend ist. Typische Kontrollen, die tatsächlich gut verschoben werden können, betreffen nicht ausreichend gut beurteilbare Einzelorgansysteme. Gleiches gilt für die erhöhten Widerstände in den Aa. uterinae in der 21.SSW oder eine engmaschige Kontrolle der verkürzten Zervix bei wehenlosem Uterus. Grundsätzlich sollten wir uns bei jeder Kontrolle von der Konsequenz der Untersuchung leiten lassen. Wenn sich das Management nicht ändert, so kann die Untersuchung zunächst auch vertagt werden.

Ein ähnlicher Gedankengang sollte auch während einer Untersuchung im Mittelpunkt stehen: der Vorteil einer „pragmatischen“, kürzeren Untersuchung überwiegt den Nachteil eines länger dauernden, an Perfektion ausgerichteten Untersuchungsgangs. Das Ziel sollte sein, dass die Schwangere sich so kurz wie möglich im geschlossenen Raum mit dem Arzt/der Ärztin aufhält.

Während einer durchschnittlichen feindiagnostischen Untersuchung im zweiten Trimenon ist die/der Untersuchende weniger als ein Meter von der Schwangeren entfernt. Somit gilt sie/er nach WHO-Richtlinien aufgrund der Dauer der Untersuchung und der Nähe zu der Patientin bereits als Kontaktperson der Kategorie Ib, wenn sich im Nachgang herausstellt, dass die Schwangere infiziert war und keine Maske trug [16, 17].

Daher sollte versucht werden, die gemeinsame Zeit mit der Schwangeren in einem Raum zu reduzieren. Einfache Maßnahmen können hier bereits helfen. So kann der schriftliche Befund beispielsweise verfasst werden, wenn die Patientin den Raum nach der Untersuchung verlassen hat. Manche Strukturen können auch an den gespeicherten Bildern ohne Beisein der Schwangeren gemessen und dokumentiert werden. Einige Zentren im Ausland empfehlen das Speichern von Video-Clips und 3D-Volumina und die der Übertragung der Bilder im Nachgang als ein möglicher Weg der Verkürzung des Arzt-Patienten-Kontakts.

Das bedeutet aber nicht, dass auf notwenige Untersuchungen verzichtet werden sollte. Dies beinhaltet primär eine adäquate Abklärung von diagnostizierten oder vermuteten Fehlbildungen in üblicher Art mit der Option einer diagnostischen Punktion. Natürlich sollte auf eine Punktion im Rahmen eines manifesten Infekts verzichtet werden - bei COVID-19 wird dies aber bereits durch die mütterliche Symptomatik bedingt.

Ebenso sollte auf ein adäquates Ersttrimester-Screening mit dem Fokus auf der frühen Feindiagnostik, sowie dem Präeklampsie- und Aneuploidie-Screening nicht verzichtet werden - insbesondere unter dem Aspekt der Planung der Schwangerschaft [18]. Aber auch hier stellt sich die Frage nach der Konsequenz eines auffälligen bzw. unauffälligen Ergebnisses. Kann zum Vorteil einer verkürzten Untersuchung nicht auch auf ein Präeklampsie-
Screening bei einer Erst-Gebärenden ohne Risikofaktoren verzichtet werden oder muss die frühe Feindiagnostik beispielsweise die Mundpartie beinhalten?

Für eine feindiagnostische Untersuchung im zweiten Trimenon gibt es ausreichend Gründe. Diese aufzuzählen würde den Rahmen sprengen, sie sind uns alle hinreichend bekannt. Diese haben natürlich auch in diesen Zeiten Bestand. Jedoch erlaubt das zweite Screening eine größere zeitliche Flexibilität und kann problemlos zu einem späteren Zeitpunkt, ggf. sogar in Kombination mit dem dritten Screening erfolgen. Auch hier gelten wieder die oben aufgezeigten Aspekte der Rationierung des Arzt-Patienten-Kontakts zur Infektionsprävention. Diesem Vorteil steht aber der Nachteil einer ggf. verspäteten Diagnose einer komplexen Fehlbildung gegenüber.

\section{Mögliche Ansätze für die eigene Praxis}

Die vorausschauende Planung des Sprechstundenablaufs wurde bereits thematisiert und soll die Wahrscheinlichkeit einer Infektion in der Praxis reduzieren. Auch während des Besuchs in der Praxis oder der Klinik lassen sich viele Abläufe optimieren.

Die hier aufgezeigten Ansätze sind als Anregungen gedacht ohne den Anspruch auf Vollständigkeit zu erheben.

\section{Triage der Schwangeren bei Eintritt in die Praxis oder Klinik}

- Bei einem Verdachtsfall oder einer Kontaktperson bietet es sich an, die Indikation für die Untersuchung zu hinterfragen. Sollte diese gegeben sein, sollte die Schwangere am Ende der Sprechstunde gesehen werden, nachdem alle anderen Schwangeren das Wartezimmer bereits verlassen haben.

- Verdachtsfälle, Kontaktpersonen und bisher unauffällige Schwangere sollten getrennt warten - wenn möglich sollte die Untersuchung bei Verdachtsfällen und Kontaktpersonen um 14 Tage verschoben werden.

- Symptomatische Schwangere, insbesondere Patientinnen mit Dyspnoe sollten durch die speziell eingerichteten Notaufnahmen beurteilt werden.

- Patientinnen sollten alleine kommen.

- Bei Ankunft in der Praxis sollte der Schwangeren die Möglichkeit gegeben werden, sich intensiv (30 sek) die Hände zu waschen und/oder zu desinfizieren.

- Wenn möglich sollten die Schwangeren sowohl im Warte- als auch im Anmeldebereich einen Abstand von 2 m voneinander und zum Praxisteam einhalten. Auch durch eine Plexiglasscheibe lässt sich das Praxisteam schützen.

\section{Vorbereitung der Untersuchung}

- Wenn es die Räumlichkeiten zulassen, sollte für die Verdachtsfälle und Kontaktpersonen ein eigenes Untersuchungszimmer bereitgestellt werden, das nicht anderweitig verwendet wird. In diesem Raum sollte sich nur das wirklich notwendige Untersuchungsmaterial befinden.

- Für die Untersuchung von Verdachtsfällen und Kontaktpersonen sollte ein Schutzanzug, eine FFP 2/3-Maske, doppelte 
Handschuhe und eine Schutzbrille angezogen werden, bevor die Patientin den Raum betritt.

- Die Untersuchung von Verdachtsfällen und Kontaktpersonen sollte durch einen erfahrenden Arzt erfolgen, um die Untersuchung möglichst schnell und zielführend zum Abschluss zu bringen.

- Sowohl die Oberflächen des Ultraschallgeräts und die Schallköpfe als auch die Liege und der Computer-Arbeitsplatz (insbesondere Tastatur, Maus, Telefon) und sonstige häufig berührte Oberflächen (zum Beispiel Lichtschalter und Kugelschreiber) im Untersuchungszimmer sollten regelmäßig gereinigt/desinfiziert werden. Auch das Handy ist eine potentielle Erregerquelle.

- Es sollten kleine, wiederverschließbare Gelflaschen verwenden werden, um potentielle Erregerreservoire zu vermeiden.

- Einmalhandtücher aus Papier sind gegenüber den Stoffwindeln und vor allem den selbst mitgebrachten Handtüchern zu bevorzugen. Wer auf Stoffwindeln dennoch nicht verzichtet will, sollte diese separat aufbewahren und bei über $60^{\circ} \mathrm{C}$ waschen.

- Das gesamte Team sollte mindestens eine einfache MundNasen-Schutz-Maske und Handschuhe tragen. Die Maske sollte möglichst wenig berührt werden.

- Nach Möglichkeit sollten Schwangere motiviert werden, ebenfalls eine einfache Mund-Nasen-Schutz-Maske (selbst genähte oder OP-Maske) bei Betreten der Klinik/Praxis zu tragen. Das Ziel ist, dabei vorwiegend andere Patientinnen und das Personal beim Sprechen, Husten oder Niesen vor Infektion zu schützen.

\section{Während der Untersuchung}

- Regelmäßiges Hände waschen, desinfizieren und die Verwendung von Pflegeprodukten für die Hände ist von zentraler Bedeutung zu. Gleiches gilt für das Tragen von Handschuhen während der Untersuchung.

- Das Tragen eines Mundschutzes soll die Ausbreitung einer Infektion von Seiten des Mundschutztragenden reduzieren. Eine übliche Mund-Nasen-Maske oder FFP1-Maske reduziert aber nicht die eigene Ansteckungsgefahr, sondern lediglich das Verbreitungsrisiko.

- Durch das Tragen einer FFP 2/3-Maske und Handschuhen während der Untersuchung kann laut Robert Koch Institut auf eine Quarantäne verzichtet werden, wenn sich im Nachgang eine Infektion der Schwangeren herausstellt - vorausgesetzt ist natürlich Symptomfreiheit.

- Wer für sich eine FFP 2/3-Maske zum Eigenschutz trägt, wird während der Untersuchung nur wenig sprechen können. Insofern ist an eine ausreichende vor- und nachbereitende Besprechung mit der Schwangeren zu denken. Hierfür sollte ein ausreichender Abstand zwischen dem Arzt und der Patientin von mindestens $2 \mathrm{~m}$ berücksichtigt werden. Beim Vorgespräch können schriftliche Aufklärungen im Vorfeld hilfreich sein.

- Wenn möglich sollten alle Untersuchungen, zum Beispiel auch Blutabnahmen, in einem Raum erfolgen und unnötige Raumwechsel vermieden werden.
- Die Anzahl der Personen in einem Raum sollte auf ein Minimum beschränkt werden. In dieser Zeit stellt jede weitere Person wie Studierende, Hospitanten und Praktikanten eine zusätzliche potentielle Infektionsquelle dar.

Insgesamt sollte der gesamte Untersuchungsgang zu kurz wie möglich gehalten werden.

\section{Nach der Untersuchung}

- Nach jeder zweiten Patientin sollte das Untersuchungszimmer gelüftet werden. Solche „Verschnaufpausen“ helfen auch dem Personal Pausen einzulegen und die anstrengende FFP-Maske kurz abzunehmen.

- Nach den Vorgaben des Robert-Koch-Instituts lassen sich die FFP-Masken und der Mund-Nasen-Schutz bei Materialknappheit von der jeweiligen Person mehrfach verwenden, wenn sie nicht kontaminiert bzw. durchfeuchtet wurden [19].

- SARS-V2 Virus ist ein Virus, das mit einfacher Seife (Tenside) und Desinfektion zu beseitigen ist. Nach der Untersuchung sollte der Abdominalschallkopf trockengewischt und entsprechend gereinigt werden [20]. Idealerweise kann ein Desinfektionstuch verwendet werden. Bei Knappheit von Desinfektionsmitteln muss auf Alternativen ausgewichen werden.

- Regelmäßige Kontrollen des eigenen Teams sollen ebenfalls potentielle Infektionsquellen aufdecken. Während derzeit regelmäßige PCR- und Antikörper-basierte Tests nicht möglich sind, lassen sich doch problemlos einfach die Temperatur messen und die typischen Symptome abfragen.

- Auf Teambesprechungen sollte vorübergehend verzichtet werden. Alternativ sollten diese web-basiert erfolgen.

- Auch während den Pausen sollte das Abstandsgebot zwischen den Mitarbeitern Berücksichtigung finden.

- Da die globale und eigene Situation von vielen als existentielle Bedrohung empfunden wird, sollte dem gemeinsamen Austausch genügend Raum gegeben werden. Gegebenenfalls lassen sich die Ängste in einem moderierten Gespräch auflösen.

\section{Fazit}

Viele Kollegen improvisieren täglich, um den Schwangeren und den Mitarbeitern in Zeiten der Corona-Pandemie gerecht zu werden. Zum einen stehen wir weiterhin für hohe Qualität in der Schwangerschaftsvorsorge und Betreuung von Risikoschwangerschaften ein, zum anderen möchten wir weder die Schwangere noch unsere Mitarbeiter oder uns selbst gefährden. Wir hoffen, dass die dargelegten empirischen Überlegungen behilflich sein können, um das Abstands- und Hygienegebot im Alltag umzusetzen.

\section{Conflict of Interest}

The authors declare that they have no conflict of interest. 
Literatur

[1] Centers of Disease Control and Prevention. Pregnancy \& Breastfeeding Information about Coronavirus Disease. 2019 https://www.cdc.gov/coro navirus/2019-ncov/need-extra-precautions/pregnancy-breastfeeding. html?CDC_AA_refVal=https\%3A\%2F\%2Fwww.cdc.gov\%2Fcoronavirus\% 2F2019-ncov\%2Fprepare\%2Fpregnancy-breastfeeding.html; aufgerufen am 2.April 2020

[2] Robert Koch Institut. SARS-CoV-2 Steckbrief zur Coronavirus-Krankheit2019 (COVID-19). https://www.rki.de/DE/Content/InfAZ/N/Neuartiges_ Coronavirus/Steckbrief.html; aufgerufen am 2.April 2020

[3] Abu-Rustum RS, Akolekar R, Sotiriadis A et al. ISUOG Consensus Statement on organization of routine and specialist obstetric ultrasound services in the context of COVID-19. Ultrasound Obstet Gynecol. 2020. [im Druck]

[4] Poon LC, Yang H, Lee JCS et al. ISUOG Interim Guidance on 2019 novel coronavirus infection during pregnancy and puerperium: information for healthcare professionals. Ultrasound Obstet Gynecol. 2020 [im Druck]

[5] Royal College of Obstetricians and Gynaecologists. Coronavirus (COVID-19) Infection in Pregnancy.; aufgerufen am 2.April 20202020 https://www. rcog.org.uk/globalassets/documents/guidelines/2020-03-28-covid19pregnancy-guidance.pdf

[6] German Board and College of Obstetrics and Gynecology. Empfohlene Präventionsmaßnahmen für die geburtshilfliche Versorgung in deutschen Krankenhäusern und Kliniken im Zusammenhang mit dem Coronavirus. 2020 https://www.dggg.de; aufgerufen am 2.April 2020

[7] American College of Obstetricians and Gynaecologists. Novel Coronavirus 2019 (COVID-19). https://www.acog.org/clinical/clinical-guidance/prac tice-advisory/articles/2020/03/novel-coronavirus-2019; aufgerufen am 2. April 2020

[8] World Health Organization. Q\&A on COVID-19, pregnancy, childbirth and breastfeeding. https://www.who.int/news-room/q-a-detail/ q-a-on-covid-19-pregnancy-childbirth-and-breastfeeding; aufgerufen am 2.April 2020

[9] Robert Koch Institut. Empfehlungen des RKI zu Hygienemaßnahmen im Rahmen der Behandlung und Pflege von Patienten mit einer Infektion durch SARS-CoV-2. https://www.rki.deDEContentInfAZNNeuartigesCoro navirusHygiene.html; aufgerufen am 2.April 2020
[10] Guan W], Ni ZY, Hu Y et al. Clinical Characteristics of Coronavirus Disease 2019 in China. N Engl J Med.; 2020 [im Druck]

[11] Lauer SA, Grantz KH, Bi Q et al. The Incubation Period of Coronavirus Disease 2019 (COVID-19) From Publicly Reported Confirmed Cases: Estimation and Application. Ann Intern Med. 2020 [im Druck]

[12] Dashraath P, Jing Lin Jeslyn W et al. Coronavirus Disease 2019 (COVID-19) Pandemic and Pregnancy. Am J Obstet Gynecol. 2020 [im Druck]

[13] Yu N, Li W, Kang Q et al. Clinical features and obstetric and neonatal outcomes of pregnant patients with COVID-19 in Wuhan, China: a retrospective, single-centre, descriptive study. Lancet Infect Dis. 2020 [im Druck]

[14] Yang H, Wang C, Poon LC. Novel coronavirus infection and pregnancy. Ultrasound Obstet Gynecol 2020; 55: 435-437

[15] Chen H, Guo J, Wang C et al. Clinical characteristics and intrauterine vertical transmission potential of COVID-19 infection in nine pregnant women: a retrospective review of medical records. Lancet 2020; 395 : 809-815

[16] Robert Koch Institut. Kontaktpersonennachverfolgung bei respiratorischen Erkrankungen durch das Coronavirus SARS-CoV-2. https://www. rki.deDEContentInfAZNNeuartigesCoronavirusKontaktpersonManage ment.html; aufgerufen am 2.April 2020

[17] Robert Koch Institut. Kontaktpersonennachverfolgung bei SARS-CoV-2 Infektionen für medizinisches Personal. https://www.rki.de/DE/Content/ InfAZ/N/Neuartiges_Coronavirus/Kontaktperson/Grafik_Kontakt_HCW. html; aufgerufen am 2.April 2020

[18] Kozlowski P, Burkhardt T, Gembruch U et al. DEGUM, ÖGUM, SGUM and FMF Germany Recommendations for the Implementation of First-Trimester Screening, Detailed Ultrasound, Cell-Free DNA Screening and Diagnostic Procedures. Ultraschall in Med 2019; 40: 176-193

[19] Robert Koch Institut. Mögliche Maßnahmen zum ressourcenschonenden Einsatz von Mund-Nasen- Schutz (MNS) und FFP-Masken in Einrichtungen des Gesundheitswesens bei Lieferengpässen im Zusammenhang mit der neuartigen Coronavirus- Erkrankung COVID-19. https://www. rki.de/DE/Content/InfAZ/N/Neuartiges_Coronavirus/Ressourcen_scho nen_Masken.pdf?__blob=publicationFile; aufgerufen am 2.April 2020

[20] Müller T, Martiny H, Merz E et al. DEGUM Recommendations on Infection Prevention in Ultrasound and Endoscopic Ultrasound. Ultraschall in Med 2018; 39: 284-303 